\title{
The Use of Utterance Politeness by Nursemaid in Creating Character of Homeless Children
}

\author{
Ristiyani, Mila Roysa, Muhammad Noor Ahsin \\ Indonesian Language and Literature Education Department, Universitas Muria Kudus, Indonesia \\ Corresponding author: ristiyani@umk.ac.id
}

\begin{abstract}
This study deal with the utterance politeness principles obedience used by nursemaid in creating and improving the character of homeless children in house shelter. There were two types of data collected. First, the data were selected by the video about the parenting interaction among nursemaid with homeless children in house shelter. Secondly, the data were collected via responses to the intention of utterance which used by nursemaid in creating a character of homeless children in house shelter. The data were obtained via data sources involving nursemaid and homeless children. The nursemaid who was in shelter used as a place of research. There were 191 utterances nursemaids who obey the principles of politeness on each maxim, i.e. 91 utterances of Tact Maxim, 16 utterances of Generosity Maxim, 22 utterances of Appobation Maxim, 17 utterances of Modesty Maxim, 28 utterances of Agreement Maxim, and 17 utterances of Symphaty Maxim.
\end{abstract}

Keywords: Speech Politeness, Care Interaction, Homeless Children

\section{Introduction}

The phenomenon of street children is often considered a social disease by the government, in addition to hard life, street children is not considered polite in speaking and not polite in behavior. The results of the study of Child Study Center, University of Diponegoro (Diponegoro University), Semarang (Kompas, 14/2/2015) indicated that about $28 \%$ of street children in Semarang experienced a moral crisis. They often commit acts of violence, crime, and speak not polite. The figure reinforces the finding of Duta Awam Foundation in 2014 said, from 500 street children surveyed in Semarang, 12.9 percent of them consider that it is unnecessary politeness when on the road, 48.4 percent considered necessary politeness, and 16.2 percent not familiar with manners.

Based on data from Tempo newspaper $(11 / 27 / 2015)$ moral crisis phenomenon that occured on street children was caused by two factors: environmental factors and their individual.

First, in terms of the environment, the world of street that seemed black, hard and scary and dirty, untidiness, fury, fights and lack of politeness, causing behavioral patterns of street children was contrary to social conformity that is in the midst of society. Secondly, in terms of the individual, more street children living on the streets was very less attention and their understanding of politeness.
Their lives were free to gather with everyone and many people made them susceptible to the influence of the character was not polite, even for most street children were not aware of it. Low educational background was also a significant cause of making the street children did not realize the importance of education mannered characters in the language.

The limit is the street children by Putranto (2007: 1), street children are children aged between 7-15 years who work on the streets and can disrupt the tranquility and safety of others and endanger themselves. Street children are divided into two types: children who work on the streets and children living on the streets. The first type still have contact with the family, while the second type has been no contact with the family.

House shelter according to the Ministry of Social Affairs (in Putranto, 2007) is defined as an intermediary for street children with the parties to help them. House shelter is an informal process that gives the atmosphere of street children centers realization of the system of values and norms in society. Interactions that occur in the house shelters are expected to provide positive feedback for the development of street children.

The nursemaid as a person who is very influential in the lives of street children should be an example in everyday life, so that the nursemaid can form a good character on street children. Nursemaids are required to have the ability to correct the wrong street behavior. 
However, in terms of correcting should use appropriate language, and based on the principle of conversation. Therefore, the nursemaid as a disseminator of knowledge and dealing directly with street children is appropriate to apply the principles of politeness by telling polite language when facing delinquency or behavior are less well on street children.

Politeness principle (politeness principle) with respect to the rules about social things, aesthetic, and moral in speech act (Grice in Rustono 1999: 66). The politeness concept of speech act is formulated in the form of rules, some are described in terms of strategy formulation. The concept of politeness that are formulated in the form of rules forms the principle of politeness, while the concept of modesty is formulated in terms of strategy, formed a theory of politeness (Rustono 1999: 66).

Briefly Lakoff (2008) argues that there are three rules that must be followed to the speech to have politeness characteristics. The third rule is that formality (formality), insecurity (hesitancy), and the similarity (equality). Completely Leech (2008: 123) suggests politeness principle which includes six maxim, namely (a) (tact maxim), (b) (generosity maxim), (c) (appobation maxim), (d) (modesty maxim), (e) (agreement maxim), and (f) (symphaty maxim). Each maxim contains advice or instructions.

The problems studied is what obeynce to principles of politeness utterance used by nursemaids in forming the character of street children in house shelter.

\section{Methods}

The research was conducted at Children's Shelter Nations (RSAB) Soegijapranata Social Foundation. The subjects were nursemaids at house shelters. This study was designed in pragmatic design triggered by Leech (1983) by basing analysis of the functions of language (language functions) expressed concretely in acts of speech with a qualitative approach that utilizes natural setting, direct data sources, and researcher as the main instruments (human instrument).

Data collected for the purposes of this study were two types. First, the data selected video about the parenting speaking interaction between nursemaid with street children in house shelter. The second data was data in response to the intention of utterances used nursemaid in creating the character of street children in house shelter. The data was obtained from data sources involving nursemaid and street children. Nursemaid referred to in this study was nursemaid who was in shelter used as a place of research.

The instrument used in this study included 1) observation guidelines to identify: (1) the selected video footage shows the interaction of parenting (2) nursemaid interviews guidelines to describe the response to the intent of utterance used in the care interaction.

\section{Results and Discussion}

Nursemaid Politeness utterance in creating the character of street children was a conversation that took place between the nursemaid and street children (speaker and hearer) which was compliance with the principles of politeness. Compliance of politeness principle could occur when speakers used right speech level (Leech 1983).

There were 191 utterances nursemaids who obey the principles of politeness on each maxim, namely (1) 91 utterances of Tact Maxim, (2) 16 utterances of Generosity Maxim, (3) 22 utterances of Appobation Maxim, (4) 17 utterances of Modesty Maxim, (5) 28 utterances of Agreement Maxim, and (6) 17 utterances of Symphaty Maxim.

Politeness utterance based on tact is that obey tact maxim. Tact maxim is maxim contains advice relating to the charging of fees to the other as light as with profit as much as possible. In harmony with this definition the maxim explained into two sub maxim that minimize fees to other and maximize the benefit to others as a hearer. Nursemaid Politeness utterance in creating the character of street children, often tinged with impositif or directive and declarative utterance with various functional modes, as utterances commonly used to certify compliance in the maxim.

Here was the nursemaid utterance in creating the character of the street children who represented tact maxim, nursemaid utterances that was affecting street children to get close to nursemaid.

\section{Conclusion}

Based on data analysis could be concluded that the overall nursemaid utterance uttered by complying with the politeness 
principles on each maxim could serve as a tool in creating the character of the street children to the success of the creating character of children across the country, and in an attempt to build a foundation for the establishment a civilization thatwas prosperous and glorious. The complete findings of this study as followed

There were 191 nursemaid utterances who obey the principles of politeness on each maxim, namely (1) 91 utterances of Tact Maxim, (2) 16 utterances of Generosity Maxim, (3) 22 utterances of Appobation Maxim, (4) 17 utterances of Modesty Maxim, (5) 28 utterances of Agreement Maxim, and (6) 17 utterances of Symphaty Maxim.

From 191 of nursemaid utterances were applied on the occasion of morning prayer, breakfast, play, community service, and study at night. The tool used was the direct utterance that served as a tool in creating the character of the street children were implanted through the ten pillars of education character of street children were (l) nursemaid utterance who obeyed the principles of politeness, tact maxim, generosity maxim, appobation maxim, modesty maxim, agreement maxim, sympathy maxim, served as a tool in the creating of street children character relate to ourselves and others (personal, family, social environment, and our fellow beings), (2) nursemaid utterance who obeyed the principles of politeness, tact maxim, generosity maxim, appobation maxim, modesty maxim, agreement maxim, sympathy maxim, served as a tool in creating street children character realated to the Adversity Quotient (AQ) mixed attitudes and behaviors development that incorporated Intellectual Quotient, Intellectual Quotient, Emotional Quotient and Spiritual Quotient (IQ, EQ and SQ), (3) nursemaid utterance who obeyed the principles of politeness, tact maxim, generosity maxim, appobation maxim, modesty maxim, agreement maxim, sympathy maxim, served as as a tool in the creating of street children character related to the nation (world: nature, science and technology, and employment), (4) nursemaid utterance who obeyed the principles of politeness, tact maxim, generosity maxim, appobation maxim, modesty maxim, agreement maxim, sympathy maxim, served as tool in the creating of street children character related to God Almighty. As parenting used was situational parenting. That was, the parenting adapted to the conditions of street children and nursemaid.

\section{References}

Kompas. 2015. Krisis santun Anak Jalanan. edisi 14 Februari 2015. Sunarti dan Asra. 2014. Metode Pembelajaran. Bandung: CV Wacana Prima.

Lakoff, R. 1975. Language and Women's Place. New York: Harper Colophon Books.

Leech, Geoffrey. 1983. The Principles of Pragmatics. London: Longman.

Rustono. 1999. Pokok-Pokok Pragmatik. Semarang: IKIP Semarang Press.

Tempo. 2015. "Lampu Merah, di Situlah Hidupku".Edisi 27 November 2015. 